\title{
Pengaruh Praktik Akuntansi Manajemen Terhadap Perubahan Organisasi dan Kinerja Organisasi Pada Sektor Publik di Kota Semarang
}

\author{
Devina Ratnasari ${ }^{1}$ \\ Clara Susilawati ${ }^{2 *}$ \\ Universitas Katolik Soegijapranata \\ *Corresponding author email:clara@unika.ac.id
}

\begin{abstract}
The main purpose of this research is to examine the effect of management accounting practices on organizational change and organizational performance. Previous empirical studies have shown that the success of management accounting practices in public sector organizations has not been convincing so that it raises doubts regarding the effectiveness of these practices in encouraging organizational change and improving performance. The sample are staff from 8 Government Agencies, 21 Government Offices, 6 Regional Companies, 17 Government Administrations (Districts), and 1 Regional Hospital in Semarang. Data analytical technique used in this research is SEM PLS. The results show that contemporary management accounting practices are positively associated with organizational change and organizational performance. The results also show that, when the public sector increasingly uses contemporary management accounting practices, changes will often occur in these organizations and these practices are able to facilitate the public sector to improve its performance. However, the results that traditional management accounting practices are not associated with organizational change and organizationanl performance.
\end{abstract}

Keywords: management accounting, public sector, organizational change, organizational performance.

\begin{abstract}
Abstrak
Tujuan utama penelitian ini adalah untuk mengetahui pengaruh praktik akuntansi manajemen terhadap perubahan organisasi dan kinerja organisasi pada sektor publik. Studi empiris terdahulu menunjukkan keberhasilan praktik akuntansi manajemen pada organisasi sektor publik belum menyakinkan sehingga memunculkan keraguan terkait dengan keefektifan praktik-praktik tersebut dalam mendorong perubahan organisasi dan peningkatan kinerja. Sampel diambil dari 8 Badan Pemerintah, 21 Dinas Pemerintah, 6 Perusahaan Daerah, 17 Administrasi Pemerintah (Kecamatan), dan 1 RSUD. Pengujian hipotesis pada penelitian ini menggunakan SEM PLS. Hasil penelitian menunjukkan bahwa praktik akuntansi manajemen kontemporer berhubungan positif dengan perubahan organisasi dan kinerja organisasi. Hal ini menunjukkan bahwa, ketika sektor publik semakin sering menggunakan praktik akunntansi manajemen kontemporer maka perubahan-perubahan akan sering terjadi pada organisasi tersebut dan praktik akuntansi manajemen kontemporer mampu memfasilitasi sektor publik untuk meningkatkan kinerjanya. Namun hasil penelitian ini menunjukkan bahwa praktik akuntansi manajemen tradisional tidak berhubungan dengan perubahan organisasi dan praktik akuntansi manajemen tradisional tidak berhubungan dengan kinerja organisasi.
\end{abstract}

Kata kunci: akuntansi manajemen, sektor publik, perubahan organisasi, kinerja organisasi. 


\section{PENDAHULUAN}

Sektor publik sering dipersepsikan sebagai tidak efisien dan efektif dalam menjalankan operasinya (Antwi et al., 2008), padahal sektor publik memiliki peran penting dalam perekonomian (Conley, 2005). Perubahan pada organisasi sektor publik seharusnya terus dilakukan untuk memberikan pelayanan publik yang lebih baik dengan cara yang efektif dan efisien. Beberapa penelitian berusaha mendorong potensi praktik akuntansi manajemen kontemporer pada sektor publik (Lapsley dan Wright, 2004 ; Chia dan Koh, 2007 ).

Perubahan dalam bidang finansial dan administrasi pada organisasi sektor publik telah banyak dilakukan dan demikian pula perbaikan manajemen publik diseluruh dunia (Nuhu et al., 2016). Perubahan dalam manajemen sektor publik tersebut seperti New Public Management dan perundang-undangan nasional seperti National Competition Policy di Australia, Collaborative Public Management di Amerika Serikat, dan State Sector dan Public Finances Act di New Zealand di akhir tahun 1990-an (Christensen dan Lægreid, 2007; Hoque dan Moll, 2001). Hood (1995) menemukan bahwa pembaruan tersebut menghasilkan peningkatan fokus pada akuntabilitas, efisiensi dan efektivitas pada organisasi sektor publik. Beberapa penelitian menunjukkan bahwa organisasi sektor publik mengadopsi praktik manajemen seperti pada sektor privat (Farneti dan Guthrie, 2008; Hood, 1995; Lapsley, 2009; Parker dan Gould, 1999). Penelitian yang dilakukan Lapsley (2009) dan Messner (2009), mengindikasikan adanya penggunaan praktik akuntansi manajemen di sektor publik seperti pada sektor privat.

Perubahan dan peningkatan kinerja perlu di tingkatkan untuk menyediakan pelayanan yang lebih baik pada publik (Holmes et al.,2006 ; Lapsley, 2009 ). Praktik akuntansi manajemen tradisional membatasi kemampuan organisasi untuk melakukan perubahan (Lapsley dan Oldfield ,1999) sehingga sebagai alternatif, praktik akuntansi manajemen yang baru (kontemporer) merupakan alternatif untuk mendorong terjadinya perubahan di sektor publik (Maiga dan Jacobs, 2008; Sarkis, 2001). Selain itu Chenhall dan Langfield (1998) juga menemukan praktik akuntansi manajemen kontemporer berpotensi untuk membantu menetapkan biaya-biaya secara efektif, dan meningkatkan efisiensi dan efektifitas dalam kegiatan operasi organisasi sektor publik (Ashworth et al., 2009). Beberapa studi meneliti peran praktik akuntansi manajemen dalam mempromosikan perubahan dan kinerja organisasi di sektor privat, namun penelitian-penelitian tersebut tidak konsisten dan tidak meyakinkan (Jackson dan Lapsley, 2003) karena sebagian penelitian ada yang melaporkan hubungan positif antara digunakannya seperangkat praktik akuntansi manajemen kontemporer dengan perubahan dan kinerja organisasi (King et al., 2010; Maiga dan Jacobs, 2008; Modell, 2001) dan ada juga studi yang tidak menemukan hubungan antara praktik akuntansi manajemen kontemporer dengan kinerja dan perubahan organisasi. (Farragher et al., 2001; Hoque, 2004).

Terbatasnya bukti empiris yang menunjukkan keberhasilan praktik akuntansi manajemen pada organisasi sektor publik, memunculkan keraguan terkait dengan keefektifan praktik-praktik tersebut, apakah hanya sekedar hasil adopsi atau paksaan (Jackson dan Lapsley, 2003) yang didasarkan pada imitasi dari praktik-praktik akuntansi manajemen di sektor privat daripada pertimbangan yang rasional (Newell et al.,2001). Nuhu et al. (2016) meneliti prevalensi atau kelaziman diterapkannya praktik akuntansi manajemen pada sektor publik, serta meneliti hubungan antara penggunaan praktik-praktik akuntansi manajemen dengan perubahan dan kinerja organisasi pada sektor publik di Australia. Hasil penelitian menunjukkan bahwa praktik akuntansi manajemen tradisional lebih umum digunakan pada sektor publik daripada praktik akuntansi manajemen kontemporer. Padahal praktik akuntansi 
manajemen tradisional itu sendiri tidak efisien jika diterapkan pada sektor publik (Lapsley dan Oldfield, 1999).

Perbedaan penelitian ini dengan penelitian sebelumnya adalah pada sampel yang digunakan. Nuhu menggunakan sampel organisasi sektor publik di Australia, sedangkan penelitian ini menggunakan sampel sektor publik di kota Semarang, dengan tujuan untuk menambah validitas eksternal yaitu generalisasi kesimpulan dari suatu studi penelitian dengan menggunakan sampel yang berbeda. Karakteristik organisasi sektor publik di setiap negara berbeda-beda dipengaruhi oleh budaya setiap negara, sehingga efektifitas praktik akuntansinya kemungkinan juga berbeda. Kontribusi penelitian ini adalah menyediakan wawasan empiris kedalam prevalensi dan efektifitas dari praktik akuntansi manajemen di sektor publik. Tujuan dari penelitian ini adalah menguji prevalensi praktik akuntansi manajemen tradisional dan kontemporer pada sektor publik, dengan membandingkan ke dua praktik tersebut mana yang lebih sering atau umum digunakan di sektor publik. Tujuan kedua dari penelitian ini adalah untuk menguji hubungan antara praktik akuntansi manajemen dengan perubahan dan kinerja organisasi pada sector publik di kota Semarang.

\section{LANDASAN TEORI DAN PENGEMBANGAN HIPOTESIS}

\section{Praktik Akuntansi Manajemen}

Praktik akuntansi manajemen adalah sistem informasi organisasi yang menyediakan informasi relevan dalam rangka menambah nilai pada kostumer dan organisasinya (Langfield, 2009). Praktik akuntansi manajemen terbagi menjadi dua berdasarkan periode pengembangannya dan karakteristiknya, yaitu : praktik akuntansi manajemen tradisional dan praktik akuntansi manajemen kontemporer.

Praktik akuntansi manajemen tradisional merujuk pada praktik yang memiliki fokus jangka pendek, dan hanya berorientasi pada kegiatan internal dan keuangan (Chenhall dan Langfield, 1998a; Pavlatos dan Paggios, 2008). Sedangkan praktik akuntansi manajemen kontemporer merujuk pada praktik yang menghubungkan operasi-operasi,proses-proses,dan atau aktivitas-aktivitas dengan hasil strategi (Chenhall dan Langfield, 1998b; Hyvönen, 2005). Secara spesifik, karena praktik manajemen kontemporer membantu mengimplementasikan prioritas strategi, praktik akuntansi manajemen kontemporer dianggap sebagai fokus strategis (Chenhall dan Langfield, 1999; Kaplan dan Norton, 2001). Praktik akuntansi manajemen kontemporer juga fokus pada kejadian historis dan masa depan, dan bersifat antar organisasi.

Tipe-tipe praktik akuntansi manajemen kontemporer yang digunakan pada penelitian ini adalah: 1. Benchmarking: suatu proses yang biasa digunakan dalam manajemen atau umumnya manajemen strategis, dimana suatu unit/bagian/organisasi mengukur dan membandingkan kinerjanya terhadap aktivitas atau kegiatan serupa unit/bagian/organisasi lain yang sejenis baik secara internal maupun eksternal. 2. Activity Based Management: suatu pendekatan di seluruh sistem dan terintegrasi, yang memfokuskan perhatian manajemen pada berbagai aktivitas, dengan tujuan meningkatkan nilai untuk pelanggan dan laba sebagai hasilnya. 3. Activity Based Costing: merupakan metode penentuan HPP (product costing) yang ditujukan untuk menyajikan informasi harga pokok secara cermat bagi kepentingan manajemen, dengan mengikur secara cermat konsumsi sumber daya alam setiap aktivitas yang digunakan untuk menghasilkan produk. 4. Balanced Scorecard: merupakan suatu sistem manajemen yang menjelaskan mengenai misi serta strategi dari suatu perusahaan ke dalam 
tujuan operasional dan tolok ukur kinerja perusahaan tersebut. Balanced Scorecard sendiri memiliki makna kartu skor, maksudnya yaitu kartu skor yang akan di gunakan dalam merencanakan skor yang di wujudkan pada masa yang akan datang. Sedangkan balanced memiliki makna berimbang, yang artinya dalam mengukur kinerja seseorang atau suatu organisasi harus di ukur secara seimbang dari dua sudut pandang seperti keuangan dan non keuangan, jangka panjang dan jangka pendek, intern dan ekstern. 5. Analisis Rantai Nilai: adalah pola yang digunakan perusahaan untuk memahami posisi biayanya dan untuk mengidentifikasi cara-cara yang dapat digunakan untuk memfasilitasi implementasi dari strategi tingkat-bisnisnya. Rantai nilai menunjukkan bagaimana sebuah produk bergerak dari tahap bahan baku ke pelanggan akhir. 6. Total Quality Management: adalah strategi manajemen yang ditujukan untuk menanamkan kesadaran kualitas pada semua proses dalam organisasi. 7. Key Performance Indicator: satu set ukuran kuantitatif yang digunakan perusahaan atau industri untuk mengukur atau membandingkan kinerja dalam hal memenuhi tujuan strategis dan operasional mereka. 8. Strategic Cost Management: penggunaan data biaya untuk mengembangkan dan mengidentifiasi strategi yang unggul yang akan menghasilkan keunggulan bersaing yang berkelanjutan.

Sedangkan untuk praktik-praktik akuntansi manajemen tradisional yang digunakan pada penelitian ini adalah : 1.Strategi Perencanaan Formal yang merupakan alat pendidikan dan pelatihan manajemen yang unggul dalam melengkapi para manajer dengan suatu pemikiran mengenai strategi dan mengimplementasikannya. 2. Penganggaran untuk Perencanaan dan Pengawasan yang merupakan perencanaan keuangan perusahaan yang digunakan sebagai dasar pengendalian (pengawasan) keuangan perusahaan. 3. Penganggaran Modal yang merupakan proses kegiatan yang mencakup seluruh aktivitas perencanaan penggunaan dana dengan tujuan untuk memperoleh manfaat (benefit) pada waktu yang akan datang. 4. Analisis Biaya Manfaat yang merupakan suatu alat analisis dengan prosedur yang sistematis untuk membandingkan serangkaian biaya dan manfaat yang relevan dengan sebuah aktivitas atau proyek. 5. Analisis Varians yang merupakan proses analisis atas penyimpanganpenyimpangan yang telah terjadi, yang besar atau jumlahnya dapat diukur dengan membandingkan angka-angka yang telah dianggarkan (budgeted) terhadap realisasi, baik yang menyangkut penjualan atau pendapatan maupun beban. 6. Standard Costing yang merupakan biaya yang telah ditentukan sebelumnya untuk memproduksi satu unit atau sejumlah produk dalam periode tertentu. Standar yang dimaksud adalah harga, biaya, atau kuantitas yang ditetapkan dengan cermat yang dinyatakan atas basis per unit. 7. ROI yang merupakan rasio yang menunjukkan hasil dari jumlah aktiva yang digunakan dalam perusahaan atau suatu ukuran tentang efisiensi manajemen. Rasio ini menunjukkan hasil dari seluruh aktiva yang dikendalikan dengan mengabaikan sumber pendanaan, rasio ini biasanya diukur dengan persentase.

Praktik-praktik ini dipilih karena adanya bukti manfaat dalam praktik manajemen di sektor publik (Van helden dan Jansen, 2003; Jackson dan Lapsley, 2003). Mereka juga memasukkan kombinasi dari praktik-praktik yang meliputi semua fungsi akuntansi manajemen, termasuk pengukuran kinerja, kontrol biaya, budgeting, costing, dan fungsi manajemen biaya.

\section{Praktik Akuntansi Manajemen dan Perubahan Organisasi}

Beberapa penelitian sebelumnya mebungkapkan bahwa ketika seperangkat atau beberapa praktik akuntansi manajemen kontemporer digunakan secara bersamaan pada suatu organisasi, akan mendorong terjadinya perubahan di organisasi tersebut karena seperangkat praktik tersebut menimbulkan efek komplementer (Adler et al., 2000; Malmi dan Brown, 
2008; Sandelin, 2008). Namun, berbanding terbalik dengan praktik akuntansi tradisional, ia cenderung menghambat terjadinya perubahan di suatu organisasi, karena ia tidak dapat memenuhi kebutuhan lingkungan yang kontemporer (Kaplan dan Johnson, 1987). Hal ini diperkuat dengan penelitian Awerbuch et al. (1996) yang menekankan adanya efek constrain atau timbulnya batasan-batasan saat digunakannya praktik akuntansi manajemen tradisional tertentu.

\section{Praktik Akuntansi Manajemen dan Kinerja Organisasi}

Penelitian Nuhu et al. (2016) memberikan hasil bahwa praktik akuntansi manajemen kontemporer berhubungan positif dengan kinerja organisasi. Hasil tersebut diperkuat dengan penelitian (Adler et al., 2000 ; Chenhall, 1997) yang menyatakan bahwa penggunaan beberapa praktik akuntansi manajemen kontemporer menghasilkan kinerja organisasi yang lebih baik. Sedangkan hasil penelitian Nuhu et al , 2016 menyatakan bahwa praktik akuntansi manajemen tradisional tidak berhubungan dengan kinerja organisasi.

\section{Akuntansi Manajemen Kontemporer dan Perubahan Organisasi}

Ferreira dan Otley (2009) mengatakan bahwa untuk mencapai implementasi strategistrategi serta perubahan yang efektif, dibutuhkan seperangkat kontrol. Penggunaan seperangkat praktik akuntansi manajemen kontemporer diharapkan dapat meningkatkan efek pada perubahan organisasi, karena menimbulkan efek komplementer, atau dengan kata lain efek yang saling melengkapi ketika praktik-praktik tersebut digunakan secara bersamaan (Adler et al., 2000). Argumen ini diperkuat dengan literatur Management Control System (Malmi dan Brown, 2008; Sandelin, 2008), yang berpendapat bahwa dengan digunakannya beberapa kontrol secara luas akan memungkinkan suatu organisasi untuk mencapai tujuan atau goalnya.

Penerapan praktik-praktik akuntansi manajemen kontemporer secara bersamaan akan memberikan hasil yang lebih baik dibandingkan ketika hanya dioperasikan secara tunggal (Ittner et al., 2002). Sarkis (2002) mengatakan bahwa implementasi dari benchmarking akan lebih efektif ketika dikombinasikan dengan Key Performance Indicators. Ittner et al., (2002) juga mengemukakan bahwa implementasi Activity Based Costing akan lebih bermanfaat bila dikombinasikan dengan praktik lainnya yang lebih baik, sedangkan disisi lain Total quality Management akan lebih dikaitkan dengan ketergantungan pada penggunaan pengukuran non keuangan (Kennedy dan Widener, 2008).

Lebih jauh lagi, pada studi kasus yang dilakukan oleh Chenhall dan Langfield (1999) menemukan bahwa sistem terintegrasi termasuk ABM, KPI, dan benchmarking sudah dikembangkan untuk memfasilitasi perbaikan yang terus menerus. Penemuan tersebut mengindikasikan adanya potensi menggunakan beberapa rangkaian praktik akuntansi manajemen kontemporer pada peningkatan perubahan. Dengan demikian dirumuskan hipotesis sebagai berikut:

\section{H1: Penggunaan praktik akuntansi manajemen kontemporer berhubungan positif dengan perubahan organisasi.}

\section{Praktik Akuntansi Manajemen Kontemporer dan Kinerja Organisasi}

Organisasi akan memperoleh lebih banyak manfaat ketika menggunakan beberapa praktik akuntansi manajemen secara bersamaan (Kaplan dan Norton, 2001b). Literatur 
Management Control System berpendapat bahwa kelayakan praktik akuntansi manajemen dalam mencapai hasil yang diinginkan tergantung pada penggunaannya sebagai suatu paket ketimbang penggunaannya secara terpisah (Sandelin, 2008). Secara khusus, beberapa peneliti telah mempromosikan potensi dari praktik-praktik akuntansi manajemen kontemporer untuk digunakan secara bersamaan untuk meningkatkan hasil atau outcome. Penelitian Banker et al. (2008) mengindikasikan kemampuan praktik Activity-Based dalam meningkatkan kualitas, efisiensi dan biaya proses akan memungkinkan jika di support dengan penggunaan praktik yang mendukung juga seperti TQM. Dengan demikian dirumuskan hipotesis sebagai berikut:

\section{H2: Penggunaan praktik akuntansi manajemen kontemporer berhubungan positif dengan kinerja organisasi}

\section{Praktik Akuntansi Manajemen Tradisional dan Perubahan Organisasi}

Seperti yang sudah didiskusikan sebelumnya, diceritakan sifat alami dari praktik akuntansi manajemen tradisional adalah memiliki perilaku menghambat (Kaplan dan Johnson, 1987) . Perubahan organisasi, yang sebagian dilakukan sebagai respon terhadap perubahan di lingkungan eksternal (Wally dan Becerra, 2001), perlu didukung oleh informasi yang layak terkait dengan lingkungan eksternal. Namun, bagaimanapun juga praktik akuntansi manjamen tradisional tidak mampu memenuhi kebutuhan dari lingkungan kontemporer (Kaplan dan Johnson, 1987), melainkan, praktik tersebut justru mendorong stabilitas dan mempertahankan status quonya. Beberapa studi sebelumnya juga menggarisbawahi adanya efek menghambat dari praktik akuntansi manajemen tradisional ( Awerbuch et al., 1996).

Pada praktiknya, organisasi-organisasi cenderung menggunakan beberapa kombinasi praktik akuntansi manajemen tradisional, sebagai contohnya praktik Formal Strategic Planning biasanya diikuti dengan Planning and Control Budgeting, demikian juga dengan Capital Budgeting (Peel dan Bridge, 1998). Khususnya pada sektor publik, cenderung mengadopsi praktik-praktik akuntansi manajemen tradisional seperti Operational Budgeting, Capital Budgeting, Planning dan Variance Analysis pada praktiknya, karena praktik-praktik tersebut berorientasi pada birokrasi dan kontrol (Van helden dan Jansen, 2003). Akan tetapi, bagaimanapun juga jika orientasi sektor publik ingin berubah menuju perubahan dan fleksibilitas (Chia dan Koh, 2007), penggunaan beberapa praktik tersebut menghambat terjadinya perubahan. Dengan demikian dirumuskan hipotesis sebagai berikut :

\section{H3: Penggunaan praktik akuntansi manajemen tradisional berhubungan negatif dengan perubahan organisasi.}

\section{Praktik Akuntansi Manajemen Tradisional dan Kinerja Organisasi}

Studi sebelumnya mengenai kinerja organisasi, yang menguji efek dari beberapa praktik akuntansi manajemen tradisional menunjukkan bahwa akuntansi manajemen tradisional memiliki hubungan positif dan negatif terhadap kinerja organisasi. Sebagai contoh, penganggaran biaya tradisional untuk perencanaan dan kontrol, dengan perannya dalam mempromosikan efisiensi dengan meyakinkan bahwa standard telah tercapai, menuntun pada kinerja yang lebih baik (King et al., 2010), khususnya pada jangka pendek. Di sisi lain , penggunaan penganggaran tradisional mengancam tercapainya kinerja organisasional jangka panjang (Jensen, 2001).

Dengan demikian, karena penggunaan praktik akuntansi manajemen tradisional memiliki efek positif dan negatif pada kinerja organisasi (Awerbuch et al., 1996 ; Kaplan dan 
Norton, 2001; King et al., 2010 ; Miller et al., 2014) maka dirumuskan hipotesis sebagai berikut

\section{H4: Penggunaan praktik akuntansi manajemen tradisional berhubungan dengan kinerja organisasi.}

\section{METODE PENELITIAN}

\section{Populasi dan Sampel}

Populasi pada penelitian ini adalah 53 kepala organisasi pada sektor publik seperti kepala keuangan atau kepala sub unit pada sektor publik di Kota Semarang yang terdiri dari 8 Badan Pemerintah, 21 Dinas Pemerintah, 6 Perusahaan Daerah, 17 Administrasi Pemerintah ( Kecamatan), dan 1 RSUD. Penelitian ini menggunakan sampel kepala organisasi (seperti kepala keuangan, ataupun kepala sub unit) karena mereka dianggap memiliki pengetahuan, pengalaman, dan bertanggung jawab terhadap digunakannya praktik akuntansi manajemen pada organisasi sektor publik tempat mereka bekerja. Karena jumlah populasi yang kecil, maka sampel yang digunakan pada penelitian ini merupakan keseluruhan populasi.

\section{Sumber Data}

Data yang akan digunakan pada penelitian ini merupakan data primer, yakni data yang diperoleh langsung dari responden sebagai obyek penelitian. Data diperoleh dari responden melalui kuesioner. Kuesioner pada penelitian ini terbagi menjadi 4 bagian yaitu praktik akuntansi manajemen kontemporer, praktik akuntansi manajemen tradisional, perubahan organisasi, dan kinerja organisasi.

\section{Definisi Operasional dan Pengukuran Variabel}

\section{Praktik Akuntansi Manajemen Kontemporer}

Praktik akuntansi manajemen kontemporer merupakan persepsi responden terkait dengan tingkat intensitas digunakannya praktik akuntansi manajemen kontemporer (benchmarking, ABM, ABC balanced scorecard value chain analysis, TQM, dan KPI) di organisasi tempat dimana ia bekerja, untuk menetapkan perencanaan jangka panjang, serta berfokus pada perhitungan finansial maupun non finansial organisasi tersebut. Variabel ini diukur dengan menggunakan skala likert dengan rentang nilai 1-5 ( dari sangat tidak setuju s/d sangat setuju ). Semakin tinggi skor berarti semakin banyak dan sering praktik tersebut digunakan pada organisasi tempat dimana ia bekerja.

\section{Praktik Akuntansi Manajemen Tradisional}

Praktik akuntansi manajemen tradisional merupakan persepsi responden mengenai tingkat intensitas digunakannya praktik akuntansi manajemen tradisional (strategi perencanaan formal, penganggaran untuk perencanaan dan pengawasan, pengganggaran modal, analisis biaya manfaat, analisis variana, standard costing dan ROI di organisasi tempat dimana ia bekerja, untuk menetapkan perencanaan jangka pendek dan perhitungan finansial organisasi tersebut. Variabel ini diukur dengan menggunakan skala likert dengan rentang nilai 1-5 ( dari sangat tidak setuju s/d sangat setuju). Semakin tinggi skor berarti semakin banyak dan sering praktik tersebut digunakan pada organisasi tempat dimana ia bekerja. 


\section{Perubahan Organisasi}

Perubahan organisasi merupakan persepsi responden terhadap seberapa sering terjadinya perubahan atau modifikasi pada aktivitas-aktivitas organisasi, struktur, dan strategi yang digunakan oleh organisasi. Variabel ini diukur dengan menggunakan 13 item pernyataan yang dikembangkan oleh Dean dan Sharfman (1996) dan Gimbert et al., (2010). Pengukuran variabel ini menggunakan skala likert dengan rentang nilai dari 1 ( sangat tidak setuju ) sampai dengan 5 ( sangat setuju ). Semakin tinggi skor berarti semakin sering terjadi perubahan atau modifikasi pada aktivitas-aktivitas organisasi, struktur, dan strategi yang dipengaruhi oleh praktik akuntansi manajemen.

\section{Kinerja Organisasi}

Kinerja organisasi merupakan persepsi responden mengenai seberapa baik kualitas produk atau jasa dan efektif operasi organisasi sehingga mampu memenuhi ekspektasi konsumen. Variabel ini diukur dengan skala likert dengan rentang nilai 1-5 ( dari sangat buruk sampai dengan sangat baik). Semakin tinggi skor berarti semakin baik kinerja organisasi tempat dimana ia bekerja.

\section{HASIL DAN PEMBAHASAN}

\section{Gambaran Umum Responden}

Data responden pada penelitian ini diperoleh dari kuesioner yang telah dibagikan pada seluruh organisasi sektor publik di Kota Semarang, sesuai dengan daftar yang ada di BPS Kota Semarang tahun 2017. Dari 53 kuesioner yang telah dibagikan, seluruh kuesioner telah kembali dan diisi dengan baik dan lengkap sesuai dengan kriteria yang ditentukan. Berikut adalah gambaran umum responden pada penelitian ini :

Tabel 1

\section{Gambaran Umum Responden}

\begin{tabular}{|c|c|c|}
\hline Keterangan & Jumlah & Presentase \\
\hline \multicolumn{3}{|l|}{ Jenis Kelamin } \\
\hline a. Laki-Laki & 26 & $49 \%$ \\
\hline b. Perempuan & 27 & $51 \%$ \\
\hline \multicolumn{3}{|l|}{ Usia } \\
\hline a. $<30$ tahun & 3 & $6 \%$ \\
\hline b. $30-40$ tahun & 16 & $30 \%$ \\
\hline c. $40-50$ tahun & 18 & $34 \%$ \\
\hline d. 50-60 tahun & 16 & $30 \%$ \\
\hline e. $>60$ tahun & 0 & $0 \%$ \\
\hline \multicolumn{3}{|c|}{ Tingkat Pendidikan } \\
\hline a. S1 & 34 & $64 \%$ \\
\hline b. S2 & 15 & $28 \%$ \\
\hline c. S3 & 0 & O\% \\
\hline \multicolumn{3}{|l|}{ d. Lain - Iain : } \\
\hline SMA & 3 & $6 \%$ \\
\hline D1 & 1 & $2 \%$ \\
\hline \multicolumn{3}{|c|}{ Pengalaman Kerja } \\
\hline a. $<1$ tahun & 3 & $6 \%$ \\
\hline b. 1-5 tahun & 4 & $8 \%$ \\
\hline c. 6-10 tahun & 18 & $34 \%$ \\
\hline d. $11-15$ tahun & 9 & $17 \%$ \\
\hline e. $>15$ tahun & 19 & $36 \%$ \\
\hline
\end{tabular}


Tabel 1 menunjukkan bahwa responden penelitian ini terdistribusi cukup seimbang antara laki-laki dan perempuan, dengan presentase $49 \%$ untuk responden laki-laki dan $51 \%$ untuk responden perempuan. Sedangkan untuk kategori usia, sebagian besar responden berada di usia matang (lebih dari 30 tahun) dengan presentase 94\% atau dengan kata lain sebanyak 50 responden berusia lebih dari 30 tahun, dengan rentang paling banyak yaitu pada kisaran 40-50 tahun. Untuk tingkat pendidikan, mayoritas responden telah mencapai jenjang pendidikan Strata 1 (S1) dengan presentase sebesar 64\%. Mayoritas responden memiliki pengalaman kerja selama lebih dari 15 tahun dengan presentase $36 \%$.

\section{Hasil Pengujian Data}

Data dalam penelitian ini diuji validatas dan reliabilitasnya. Pengujian validitas pada penelitian ini menguji validitas konstruk dengan menggunakan aplikasi Smart PLS 3. Data dinyatakan valid jika nilai loading factor memiliki nilai $>0.7$ dan nilai AVE serta communality $>0.5$. Pengujian reliabiltas dilakukan dengan menggunakan alat uji PLS . Indikator yang digunakan pada uji reliabilitas ini antara lain cronbach's alpha dan composite reliabity. Data dinyatakan reliabel jika nilai cronbach's alpha dan composite reliabity > 0.6.

\section{Uji Validitas}

Validitas yang akan diuji pada penelitian ini ialah validitas konstruk dengan menggunakan aplikasi SmartPLS 3. Data dinyatakan valid jika nilai loading factor memiliki nilai > 0.7 dan nilai AVE serta communality $>0.5$. Tabel 2 menyajikan nilai loading factor dari masing-masing variabel.

\section{Tabel 2}

\section{Hasil Pengujian Loading Factor Akhir}

\begin{tabular}{|l|r|l|l|l|}
\hline & CMAP & KO & PO & TMAP \\
\hline CMAP2 & 0.819 & & & \\
\hline CMAP3 & 0.819 & & & \\
\hline CMAP4 & 0.716 & & & \\
\hline CMAP5 & 0.798 & & & \\
\hline CMAP6 & 0.830 & & & \\
\hline KO2 & & 0.782 & & \\
\hline KO3 & & 0.803 & & \\
\hline KO4 & & 0.826 & & \\
\hline K05 & & 0.806 & & \\
\hline P010 & & & 0.846 & \\
\hline P011 & & & 0.824 & \\
\hline P012 & & & 0.890 & \\
\hline P013 & & & 0.869 & \\
\hline P03 & & & 0.767 & \\
\hline P06 & & & 0.840 & \\
\hline P07 & & & 0.856 & \\
\hline P09 & & & 0.829 & \\
\hline TMAP5 & & & & 0.904 \\
\hline TMAP6 & & & & 0.870 \\
\hline TMAP7 & & & & 0.812 \\
\hline
\end{tabular}

Setelah indikator yang memiliki nilai loading kurang dari 0.7 dieliminasi, dilakukan pengujian validitas ulang, sehingga didapatkan hasil yang dapat dilihat pada tabel 3 berikut ini: 
Tabel 3

Hasil Pengujian Validitas

\begin{tabular}{|c|c|c|c|}
\hline VARIABEL & AVE DAN COMMUNALITY & KRITERIA & KETERANGAN \\
\hline CMAP & 0.636 & Nilai AVE dan Communality & VALID \\
\hline TMAP & 0.647 & harus $>0.5$ agar & VALID \\
\hline PO & 0.707 & dinyatakan VALID & VALID \\
\hline KO & 0.744 & & VALID \\
\hline
\end{tabular}

Berdasarkan hasil pengujian ulang AVE dan communality tersebut, dapat dilihat bahwa semua variabel sudah memiliki nilai di atas 0,5 sehingga dapat dinyatakan valid.

\section{Uji Reliabilitas}

Hasil pengujian reliabilitas dapat dilihat dari nilai Cronbach's Alpha dan Composite Reliability yang disajikan dalam tabel 4 berikut ini:

\section{Tabel 4}

Hasil Pengujian Reliabilitas

\begin{tabular}{|c|c|c|c|c|}
\hline VARIABEL & CRONBACH'SALPHA & COMPOSITE RELLABILITY & KRITERIA & KETERANGAN \\
\hline CMAP & 0.856 & 0.897 & Nilai Cronbach's Alpha dan & RELLABEL \\
\hline TMAP & 0.820 & 0.880 & Composite Reliability harus & RELLABEL \\
\hline PO & 0.941 & 0.951 & dibawah 0.7 agardinyatakan & RELIABEL \\
\hline KO & 0.828 & 0.897 & RELLABEL & RELIABEL \\
\hline
\end{tabular}

Dari tabel diatas, setelah indicator yang memiliki nilai loading dibawah 0.5 dihilangkan, nilai cronbach's alpha dan composite reliability dari semua variabel memiliki nilai lebih dari 0.7 sehingga dapat dinyatakan data tersebut reliabel atau dapat diandalkan untuk pengujian selanjutnya.

Untuk memahami lebih lanjut tentang karakteristik responden, perlu dipecah lebih lanjut latar belakang responden yang digunakan dalam penelitian.

Tabel 5

Persentase Responden per Kategori

\begin{tabular}{|l|r|r|}
\hline \multicolumn{1}{|c|}{ Keterangan } & Jumlah & Presentase \\
\hline Sektor Publik & 8 & \\
\hline a. Badan Pemerintah & 22 & $15 \%$ \\
\hline b. Dinas Pemerintah & 5 & $42 \%$ \\
\hline c. Perusahaan Daerah & 17 & $9 \%$ \\
\hline d. Administrasi Pemerintah ( kecamatan ) & 1 & $32 \%$ \\
\hline e. RSUD & & $2 \%$ \\
\hline \multicolumn{2}{|c|}{53} & $100 \%$ \\
\hline Total &
\end{tabular}


Tabel 5 menyajikan persentase responden per kategori. Dari tabel dapat dilihat bahwa sebagian besar responden berasal dari dinas pemerintah diikuti kemudian administrasi pemerintah. Masing-masing sebesar $42 \%$ dan 32\%. Sementara persentase terkecil berasal dari RSUD yaitu sebesar $2 \%$.

Seperti yang telah dijelaskan sebelumnya, responden penelitian berasald ari badan pemerintah, dinas pemerintah, perusahaan daerah, administaras pemerintah (kecamatan), dan RUSD. Untuk memahami lebih lanjut penggunaan praktik akuntansi manajemen, Tabel 6 menyajikan informasi lebih detail tentang praktik akuntansi manajemen pada sektor-sektor tersebut.

Tabel tersebut menunjukkan bahwa praktik akuntansi manajemen kontemporer yang dominan digunakan pada sektor publik adalah TQM, benchmarking dan analisis rantai nilai. Adapun salah satu sektor publik yang sering menggunakan TQM adalah RSUD.

\section{Tabel 6}

\section{Praktik Akuntansi Manajemen Masing-Masing Sektor}

\begin{tabular}{|c|c|c|c|c|c|c|}
\hline Praktik Akuntansi Manajemen & Badan Pemerintahan & Dinas Pemerintahan & Perusahaan Daerah & \begin{tabular}{|c|} 
Administrasi Pemerintah \\
(kecamatan $)$
\end{tabular} & RSUD & Total \\
\hline CMAP 1 (Benchmarking) & 0 & 5 & 1 & 3 & 0 & 9 \\
\hline CMAP 2 (ABM) & 1 & 2 & 1 & 3 & 0 & 7 \\
\hline $\operatorname{CMAP} 3(\mathrm{ABC})$ & 0 & 1 & 1 & 2 & 1 & 5 \\
\hline CMAP 4 (Balanced Scorecard) & 0 & 2 & 1 & 3 & 1 & 7 \\
\hline CMAP 5(Analisis Rantai Nilai ) & 1 & 3 & 2 & 3 & 0 & 9 \\
\hline CMAP 6(TQM) & 1 & 3 & 3 & 4 & 1 & 12 \\
\hline CMAP 7 ( KPI) & 0 & 4 & 1 & 1 & 0 & 6 \\
\hline CMAP 8 ( Strategic Cost Management) & 0 & 2 & 1 & 2 & 0 & 5 \\
\hline Jumlah & 3 & 22 & 11 & 21 & 3 & 60 \\
\hline TMAP 1 (Strategi Perencanaan Formal ) & 0 & 8 & 2 & 5 & 1 & 16 \\
\hline TMAP 2 (Penganggaran u/ Perencanaan dan Pengawasan) & 1 & 9 & 4 & 5 & 1 & 20 \\
\hline TMAP 3 ( Penganggaran Modal) & 0 & 4 & 2 & 4 & 1 & 11 \\
\hline TMAP 4 (Analisis Biaya Manfaat) & 1 & 5 & 1 & 2 & 0 & 9 \\
\hline TMAP 5 (Analisis Varian) & 0 & 2 & 1 & 3 & 0 & 6 \\
\hline TMAP 6 (Standart Costing) & 1 & 4 & 2 & 4 & 0 & 11 \\
\hline TMAP 7 ( ROI) & 0 & 2 & 2 & 1 & 0 & 5 \\
\hline Jumlah & 3 & 34 & 14 & 24 & 3 & 78 \\
\hline
\end{tabular}

TQM digunakan di rumah sakit untuk melakukan perbaikan kualitas secara terus menerus, misalnya perbaikan system secara berkesinambungan, pemberdayaan karyawan rumah sakit, kerjasama tim, dsb. Indikasi penggunaan TQM pada rumah sakit juga banyak ditemukan oleh beberapa penelitian seperti ( Muchtar, 2005; Sakantia , 2014). Sedangkan penggunaan TQM juga ditemukan pada beberapa perusahaan daerah, seperti perusda percetakan, badan pemotongan hewan dan PDAM.

Penggunaan analisis rantai nilai digunakan pada beberapa perusahaan daerah seperti badan pemotongan hewan, perusda percetakan, PDAM. PDAM memetakan kegiatannya menjadi 2, yaitu kegiatan utama dan pendukung. Kegiatan utama mencakup perencanaan, pengelolaan air, distribusi air, pelayanan tangki air, dan pelayanan pengaduan. Kegiatan pendukung meliputi manajemen sumber daya manusia, manajemen keuangan, manajemen pengadaan dan perawatan fasilitas, manajemen teknologi informasi, manajemen hubungan dengan pemerintah, lembaga dan masyarakat, telaah dan konsultasi hukum (Noveristi, 2014). Penggunaan benchmarking juga ditemukan pada PDAM, dan beberapa dinas dan kecamatan, dengan tujuan untuk mengoptimalisasi pengelolaan pelayanan publik, karena dengan diberlakukannya otonomi daerah, maka pemerintah juga harus meningkatkan kemampuan 
manajerialnya dalam mengelola sumber daya dan asset daerah yang dimilikinya (Susilo 2006). Sedangkan untuk praktik akuntansi manajemen tradisional yang dominan digunakan pada sektor publik yaitu, penganggaran untuk perencanaan dan pengawasan, strategi perencanaan formal, penganggaran modal, dan standard costing. Hampir semua golongan sektor publik dari perusahaan daerah, RSUD,dinas-dinas, kecamatan menggunakan keempat praktik tradisional tersebut, hal ini mendukung penelitian yang dilakukan oleh (Peel dan Bridge, 1998), yang menemukan adanya indikasi diterapkannya keempat praktik tersebut pada sektor publik untuk mengelola aset daerah dan memastikan bahwa standard yang ditentukan sudah tercapai (King et al., 2010).

\section{Tabel 7}

\section{Statistik Deskriptif}

\begin{tabular}{|c|c|c|c|c|c|c|c|c|c|}
\hline \multirow{2}{*}{ Variabel } & \multirow{2}{*}{ Min } & \multirow{2}{*}{ Max } & \multirow{2}{*}{ Mean } & \multirow{2}{*}{ Kisaran Teoritis } & \multirow{2}{*}{ Kisaran Aktual } & \multicolumn{3}{|c|}{ Rentang Skala } & \multirow{2}{*}{ Keterangan } \\
\hline CMAP & 1.5 & 4.9 & 3.321 & $1 \mathrm{~s} / \mathrm{d} 5$ & $1.5-4.9$ & $0-1.5$ & $1.6-3.5$ & $3.6-5.0$ & Sedang \\
\hline TMAP & 2.0 & 5.0 & 3.663 & $1 \mathrm{~s} / \mathrm{d} 5$ & $2.0-5.0$ & $0-1.5$ & $1.6-3.5$ & $3.6-5.0$ & Tinggi \\
\hline P0 & 1.0 & 4.8 & 2.463 & $1 \mathrm{~s} / \mathrm{d} 5$ & $1.0-4.8$ & $0-1.5$ & $1.6-3.5$ & $3.6-5.0$ & Sedang \\
\hline K0 & 2.3 & 5.0 & 3.799 & $1 \mathrm{~s} / \mathrm{d} 5$ & $2.3-5.0$ & $0-1.5$ & $1.6-3.5$ & $3.6-5.0$ & Tinggi \\
\hline
\end{tabular}

Hasil analisis tabulasi silang tersebut didukung oleh tabel 7 dimana statistik deskriptif menunjukkan bahwa praktik akuntansi manajemen tradisional luas digunakan pada sektor publik, ditunjukkan dengan banyaknya dan intensitas penggunaan praktik-praktik tersebut pada sektor publik daripada praktik kontemporer.

\section{Pengujian Hipotesis}

Pengujian hipotesis pada penelitian ini menggunakan uji SEM PLS. Pengujian yang dilakukan dengan menggunakan model struktural path coefficients untuk memprediksi hubungan antar variabel yang akan diuji. Pengukuran dilakukan dengan membandingkan $t$ table dan $t$-statistics. Jika nilai $t$-statistics lebih besar daripada t-table, maka hipotesis diterima. Tingkat keyakinan yang digunakan pada penelitian ini sebesar $95 \%$ dengan persentase kesalahan 5\%. Jika nilai signifikansinya $>1,96$, maka hipotesis dapat diterima.

\section{Hipotesis Pertama (H1)}

Untuk melihat hubungan antara variabel praktik akuntansi manajemen kontemporer dengan perubahan organisasi dapat kita lihat dengan membandingkan nilai t-statistic dan ttabel. Pada tabel diatas, dapat kita lihat bahwa t-statistik (1.98) dari H1 memiliki nilai lebih besar daripada t-tabelnya (1.96), dan karena t-statistik (1.98) > daripada t-tabel (1.96) maka dapat disimpulkan hipotesis pertama ini diterima. Sedangkan untuk melihat arah hubungan dari kedua variabel tersebut dapat kita lihat dari nilai koefisiennya. 
Tabel 8

Hasil Uji Hipotesis

\begin{tabular}{|c|c|c|c|c|c|c|}
\hline Hipotesis & Original Sampel| 0 & Sampel|Mean (M) & $\begin{array}{l}\text { Standard Deviation } \\
\text { (STDEV) }\end{array}$ & TStatisticis || $0 /$ /SDEV $\|$ & PValues & Kesimpulan \\
\hline H1 CMAP $\rightarrow P O$ & 0.331 & 0.367 & 0.167 & 1.980 & 0.048 & Hipotesis Diterima \\
\hline H2 CMAP $>$ KO & 0.385 & 0.391 & 0.129 & 2.986 & 0.003 & Hipotesis Diterima \\
\hline H3 TMAP $>P O$ & 0.201 & 0.182 & 0.193 & 1.043 & 0.298 & Hipotesis Ditolak \\
\hline H4 TMAP $>$ KO & 0.368 & 0.367 & 0.135 & 2.736 & 0.006 & Hipotesis Diterima \\
\hline
\end{tabular}

Hubungan kedua variabel ini memiliki arah yang positif, ditunjukkan dengan nilai koefisiennya senilai 0.331 . Hasil pengujian tersebut menunjukkan bahwa, ketika sektor publik semakin banyak dan sering menggunakan praktik kontemporer maka perubahan-perubahan akan sering terjadi pada organisasi tersebut, demikian juga sebaliknya ketika sektor publik semakin jarang dan sedikit menggunakan praktik kontemporer, maka perubahan akan lebih jarang terjadi juga. Hal ini terbukti bahwa praktik kontemporer mampu memfasilitasi sektor publik dalam melakukan perubahan, Hasil penelitian juga menunjukkan kemampuan TQM, benchmarking dan analisis rantai nilai dalam membantu sektor public, khususnya perusahaan daerah untuk melakukan perubahan ataupun perbaikan pelayanan demi terpenuhinya ekspektasi konsumen, yang dalam hal ini adalah masyarakat.

\section{Hipotesis Kedua (H2)}

Pengujian hipotesis kedua pada penelitian ini menunjukkan nilai t-statistik 2.986, lebih besar daripada t-tabelnya, 1.96, sedangkan jika kita lihat nilai koefisiennya (0.385), arah hubungan kedua variabel ini positif, sehingga dapat disimpulkan $\mathrm{H} 2$ ini diterima. Hal ini berarti, jika suatu sektor publik semakin banyak dan sering menggunakan praktik kontemporer maka kinerja organisasinya akan semakin baik, demikian pula sebaliknya jika suatu sektor publik semakin sedikit dan jarang menggunakan praktik kontemporer maka kinerja organisasinya akan semakin kurang. Hal ini berarti membuktikan bahwa praktik kontemporer mampu memfasilitasi sektor publik untuk meningkatkan kinerjanya. Penggunaan TQM, bechmarking, dan analisis rantai nilai, mendorong kinerja semakin baik.

\section{Hipotesis ketiga (H3)}

Pengujian hipotesis ketiga menunjukkan nilai t-statistik 1.04, kurang dari t-tabelnya (1.96 ) sehingga dapat disimpulkan $\mathrm{H} 3$ ditolak. Hal ini berarti ketika sektor publik tersebut semakin banyak dan sering ataupun semakin sedikit dan jarang dalam menggunakan praktik tradisional tidak akan berhubungan dengan semakin sering dan jarangnya perubahan terjadi pada sektor publik. Hal ini terjadi karena penggunaan praktik tradisional pada sektor publik, seperti yang diungkapkan oleh (King et al, 2010), hanya difungsikan sebagai perangkat kontrol saja agar standard birokrasi yang ditentukan oleh pemerintah terpenuhi, sehingga tidak mempengaruhi perubahan yang terjadi pada sektor publik tersebut, karena setiap perubahan yang ada pada sektor publik tersebut diatur oleh pemerintah pusat. 


\section{Hipotesis keempat $(\mathbf{H 4})$}

Hasil pengujian hipotesis keempat menunjukkan nilai t-statistik sebesar 2.736, lebih besar daripada t-tabelnya (1.96), sehingga dapat disimpulkan bahwa $\mathrm{H} 4$ diterima. Hal ini berarti semakin sektor publik tersebut banyak dan sering menggunakan praktik tradisional maupun tidak, tidak akan berpengaruh pada kinerja organisasi. Seperti yang sudah dijelaskan pada hipotesis ke tiga, praktik tersebut hanya difungsikan untuk kontrol dan pengawasan saja untuk memastikan standard dan tujuan birokrasi terpenuhi, oleh sebab itu pula maka hasil statistik deskriptif untuk variabel kinerja pada penelitian ini relative tinggi karena responden merasa standard dan tujuan birokrasinya sudah tercapai, maka mereka memberikan skor yang tinggi untuk kinerja organisasinya.

\section{SIMPULAN}

Secara garis besar, setelah dilakukan pengujian, didapatkan hasil penelitian sebagai berikut: 1. Penggunaan praktik akuntansi manajemen kontemporer berhubungan positif dengan perubahan organisasi sektor publik di Kota Semarang. 2. Penggunaan praktik akuntansi manajemen kontemporer berhubungan positif dengan kinerja organisasi sektor publik di kota Semarang. 3. Penggunaan praktik akuntansi manajemen tradisional tidak berhubungan dengan perubahan organisasi sektor publik di kota Semarang. 4. Penggunaan seperangkat praktik akuntansi manajemen tradisional tidak berhubungan dengan kinerja organisasi sektor publik di kota Semarang.

Melihat adanya potensi dari praktik akuntansi manajemen kontemporer, akan lebih baik jika kepala keuangan sektor publik mulai mempertimbangkan praktik tersebut jika ingin meningkatkan pelayanannya pada masyarakat, sehingga sektor publik tidak lagi di stereotype kan sebagai lembaga yang lamban, tidak efektif dan efisien dalam memberikan layanannya pada masyarakat. Hal tersebut dapat dengan memberikan sosialisasi, dilanjutkan training atau edukasi pada staff-staff, terutama staff keuangan tentang praktik akuntansi manajemen kontemporer, kemudian yang terakhir dengan membenahi budaya dalam organisasi sektor publik agar lebih fleksibel dan terbuka dalam menerima praktik baru. Penelitian ini mempunyai keterbatasan pada instrumen kuesioner yang digunakan, yang kurang komunikatif dan pemakaian bahasa yang susah dimengerti atau kurang tepat, terutama pada indikator variabel kinerja, sehingga menghasilkan hasil penelitian yang bias. Penelitian selanjutnya, disarankan untuk meninjau kembali indicator dari kinerja organisasi.

\section{DAFTAR PUSTAKA}

Adler; R., A.Everett., and M.Waldron. 2000. Advanced Management Accounting Techniques in Manufacturing: Utilization, Benefits, and Barriers to Implementation. Accounting Forum 24(2):131-50.

Antwi, K. B., F.Analoui., and D. Agyekum. 2008. Public Sector Reform In Sub-Saharan Africa: What Can Be Learnt From The Civil Service Performance Improvement Programme In Ghana? Public Administration and Development 28(4):253-264.

Ashworth, R., G. Boyne., and R. Delbridge. 2009. Escape from the Iron Cage? Organizational Change and Isomorphic Pressures in the Public Sector. Journal of 
Research and Theory 19(1):165-87.

Awerbuch, S., J. Dillard., T. Mouck., and A. Preston. 1996. Capital Budgeting, Technological Innovation and the Emerging Competitive Environment of the Electric Power Industry. Energy Policy 24(2):195-202,

Banker, R., I. Bardhan., and T. Chen. 2008. The Role of Manufacturing Practices in Mediating the Impact of Activity-Based Costing on Plant Performance. Accounting, Organizations and Society 33(1):1-19.

Chenhall, R. 1997. Reliance on Manufacturing Performance Measures, Total Quality Management and Organizational Performance. Management Accounting Research 8(2):187-206.

Chenhall. R., and K. Smith. 1998. The Relationship between Strategic Priorities, Management Techniques and Management Accounting: An Empirical Investigation Using a Systems Approach. Accounting, Organizations and Society 23(3):243-64. . 1998. Adoption and Benefits of Management Accounting Practice: An Australian Study. Management Accounting Research 9(1):1-19. . 1999. The Implementation of Innovative Mnagement Accounting Systems . Australian Accounting Review 9(3):37-46.

Chia, Y., and H. Koh. 2007. Organizational Culture and the Adoption of Management Accounting Practices in the Public Sector: A Singapore Study. Financial Accountability \& Management 23(2):189-213.

Christensen, T., and Lægreid. 2007. The Whole-of-Government Approach to Public Sector Reform. Public Administration Review 67(6):1059-66.

Conley, T. 2005. Benchmarking in the Non- profit Sector in Australia. Benchmarking: An International Journal 12(3):219-35.

Dean, J., and M. Sharfman. 1996. Does Decision Process Matter? A Study of Strategic Decision-Making Effectiveness. Source: The Academy of Management Journal Academy of Management Journal 39(2):368-96.

Farneti, F., and J. Guthrie. 2008. Italian and Australian Local Governments: Balanced Scorecard Practices. A Research Note. Journal of Human Resource Costing \& Accounting 12(1):4-13.

Farragher, E., R. Kleiman, and A.Sahu. 2001. The Association Between The Use Of Sophisticated Capital Budgeting Practices And Corporate Performance. The Engineering Economist 46(4):300-311.

Ferreira, A. and D. Otley. 2009. The Design and Use of Performance Management Systems: An Extended Framework for Analysis.Management Accounting Research 20(4):263-82.

Gimbert, X., J. Bisbe., and X. Mendoza. 2010. The Role of Performance Measurement Systems in Strategy Formulation Processes. Long Range Planning 43(4):477-97.

Holmes, J., S. Piñeres., and L. Kiel. 2006. Reforming Government Agencies Internationally: Is There a Role for the Balanced Scorecard?" International Journal of Public Administration 29(12):1125-45. 
Hood, C. 1995. The New Public Management' in the 1980s: Variations on a Theme. Accounting, Organizations and Society 20(2-3):93-109.

Hoque, Z., and J. Moll. 2001. Public Sector Reform? Implications for Accounting, Accountabil- Ity and Performance of State-Owned Entities? An Australian Perspective, International Journal of Public Sector Management 14(8):304-326.

Hoque, Z. 2004. A Contingency Model of the Association between Strategy, Environmental Uncertainty and Performance Measurement: Impact on Organizational Performance. International Business Review 13(4):485-502.

Hyvönen, J. 2005. Adoption and Benefits of Management Accounting Systems: Evidence from Finland and Australia. Advances in International Accounting 18(05):97-120.

Ittner, C., W. Lanen., and D. Larcker. 2002. Activity-Based Costing and Manufacturing Performance. Journal of Accounting Research 40(3).

Jackson, A., and I. Lapsley. 2003. The Diffusion of Accounting Practices in the New 'Managerial' Public Sector. International Journal of Public Sector Management 16(5):359-372.

Jensen, M. 2002. Corporate Budgeting Is Broken, Let's Fix It. Working Paper, Havard University

Kaplan, R., and H. Johnson . 1987. Relevance Lost: The Rise and Fall of Managament Accounting. Boston: MA : Harvard Bussines School.

Kaplan, R., and D. Norton. 2001. Transforming the Balanced Scorecard from Performance Measurement to Strategic Management: Part II. Accounting Horizons 15(2):147-60.

Kennedy, F., and S. Widener. 2008. A Control Framework: Insights from Evidence on Lean Accounting. Management Accounting Research 19(4):301-23.

King, R., P. Clarkson., and S. Wallace. 2010. Budgeting Practices and Performance in Small Healthcare Businesses. Management Accounting Research 21(1):40-55.

Langfield, K., Thorne ., and R. ilton., 2009. Management Accounting Information for Creating and Managing Value. Australia Mc Graw Hill.

Lapsley, I. 2009. New Public Management: The Cruellest Invention of the Human Spirit? 1 Abacus 45(1):1-21.

, and R.Oldfield. 1999. The Past Is the Future: Constructing Public Sector Accountants. Pacific Accounting Review 11(2):137-47.

, and E.Wright. 2004. The Diffusion of Management Accounting Innovations in the Public Sector: A Research Agenda. Management Accounting Research 15(3):355-74.

Maiga, A., and F. Jacobs. 2008. Extent of ABC Use and Its Consequences. Contemporary Accounting Research 25(2):533-66.

Malmi, T., and D. Brown. 2008. Management Control Systems as a Package-Opportunities, Challenges and Research Directions. Management Accounting 
Research 19(4):287-300.

Messner, M. 2009. The Limits of Accountability. Accounting, Organizations and Society 34(8):918-38.

Miller, C., L. Cardinal, and C. Miller. 2014. Strategic Planning And Firm Performance: A Synthesis Of More Than Two Decades Of Research. The Academy of Management Journal 37(6):1649-65

Modell, S. 2001. Performance Measurement and Institutional Processes: A Study of Managerial Responses to Public Sector Reform. Management Accounting Research 12(4):437-64.

Auditing

2009. Bundling Management Control Innovations. Accounting, \& Accountability Journal 22(1):59-90.

Muchtar, A. 2005. Analisis Manajemen Mutu Terpadu (TQM) Dalam Pelayanan Rumah Sakit. Artikel Akuntansi Manajemen, dari http://repository.ung.ac.id/hasilriset/show/ 1/116/analisis-manajemen-mutu-terpadu-tqm-dalam-pelayanan-rumah-sakit.html.

Newell, S., M. Robertson, and J. Swan. 2001. Management Fads and Fashion. Management Accounting Research 8:11.

Noveristi, N. 2014. Rencana Strategis Teknologi Informasi Dengan Pendekatan Grid Strategic Mc. Farlan (Studi Kasus: PDAM Tirtawening Kota Bandung). Skripsi, Unikom, Bandung, Indonesia

Nuhu, N. A., K. Baird., and R. Appuhami. 2016. The Association between the Use of Management Accounting Practices with Organizational Change and Organizational Performance. Advances in Management Accounting. 67-98

Parker, L. and G. Gould. 1999. Changing Public Sector Accountability: Critiquing New Directions. Accounting Forum 23(2):109-35

Pavlatos, O., and I. Paggios. 2008. Management Accounting Practices in the Greek Hospitality Industry. Managerial Auditing Journal 24(1):81-98.

Peel, M. and J. Bridge. 1998. How Planning and Capital Budgeting Improve SME Performance. Long Range Planning 31(6): 848-856.

Sakantia, A. 2014. Pengaruh Penerapan Total Quality Management (TQM) Terhadap Pencapaian Status Akreditasi Rumah Sakit Umum. Skripsi, Universitas Katolik Soegijapranata, Semarang, Indonesia

Sandelin, M. 2008. Operation of Management Control Practices as a Package-A Case Study on Control System Variety in a Growth Firm Context. Management Accounting Research 19(4):324-43.

Sarkis, J. 2001. Benchmarking for Agility. Benchmarking: An International Journal (2):88-107.

Susilo, J. 2006. Benchmarking Peningkatan Layanan Pemerintah Daerah Suatu Tinjauan Teoritis. Aplikasi Bisnis 6(9):728-740. 
Jurnal Akuntansi Bisnis, Vol. 18, No. 2, September 2020

ISSN 1412-775X (media cetak) | 2541-5204 (media online)

Van H, G. Jan and P. Jansen. 2003. New Public Management in Dutch Local Government. Local Government Studies 29(2):68-88.

Wally, S., and M. Becerra., 2001. Top Management Team Characteristicsand Strategic Changes in International Diversification: The Case of U.S. Multinationals in the Europen Community. SAGE Journals 26(2):165-188. 